\title{
Chasing the genes that control resistance to gastrointestinal nematodes
}

\author{
J.M. Behnke ${ }^{1 *}$, F. Iraqi ${ }^{2}$, D. Menge ${ }^{2}$, R.L. Baker ${ }^{2}$, J. Gibson ${ }^{2}$ and \\ D. Wakelin ${ }^{1}$ \\ ${ }^{1}$ School of Life and Environmental Sciences, University of Nottingham, \\ University Park, Nottingham, NG7 2RD, UK: ${ }^{2}$ International Livestock \\ Research Institute, PO Box 30709, Nairobi, Kenya
}

\begin{abstract}
The host-protective immune response to infection with gastrointestinal (GI) nematodes involves a range of interacting processes that begin with recognition of the parasite's antigens and culminate in an inflammatory reaction in the intestinal mucosa. Precisely which immune effectors are responsible for the loss of specific worms is still not known although many candidate effectors have been proposed. However, it is now clear that many different genes regulate the response and that differences between hosts (fast or strong versus slow or weak responses) can be explained by allelic variation in crucial genes associated with the gene cascade that accompanies the immune response and/or genes encoding constitutively expressed receptor/signalling molecules. Major histocompatibility complex (MHC) genes have been recognized for some time as decisive in controlling immunity, and evidence that non-MHC genes are equally, if not more important in this respect has also been available for two decades. Nevertheless, whilst the former have been mapped in mice, only two candidate loci have been proposed for non-MHC genes and relatively little is known about their roles. Now, with the availability of microsatellite markers, it is possible to exploit linkage mapping techniques to identify quantitative trait loci (QTL) responsible for resistance to GI nematodes. Four QTL for resistance to Heligmosomoides polygyrus, and additional QTL affecting faecal egg production by the worms and the accompanying immune responses, have been identified. Fine mapping and eventually the identification of the genes (and their alleles) underlying QTL for resistance/susceptibility will permit informed searches for homologues in domestic animals, and human beings, through comparative genomic maps. This information in turn will facilitate targeted breeding to improve resistance in domestic animals and, in human beings, focused application of treatment and control strategies for GI nematodes.
\end{abstract}

\section{Introduction}

The intestinal immune response to infection with nematodes comprises a plethora of interacting processes that are activated once the presence of the parasite and its antigens in the gut have been recognized. The host

*Fax: (0) 1159513251

E-mail: jerzy.behnke@nottingham.ac.uk protective response is driven by the Th2 lymphocyte subset and culminates in the activation of a range of potential effector mechanisms against the invading parasites (Else \& Finkelman, 1999; Behnke et al., 2000; Artis \& Grencis, 2001). Figure 1 summarizes some of the key processes involved in this type of response.

As new tools for dissecting the component processes are developed, we learn in yet more intricate detail about the molecular interactions that are involved. Different cell 


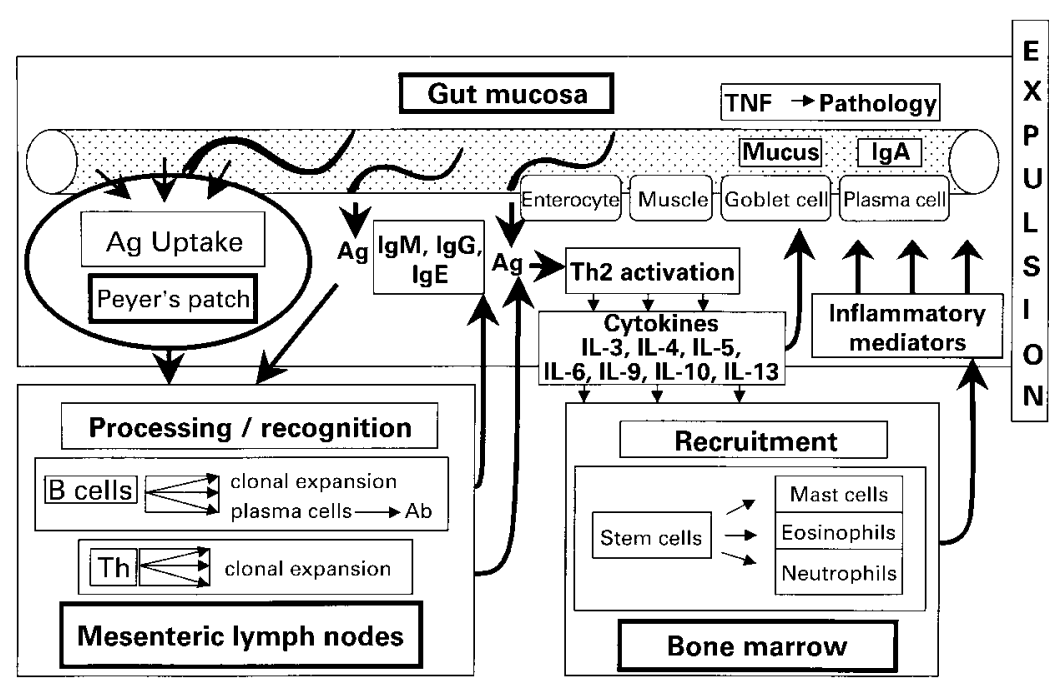

Fig. 1. Schematic diagrams summarizing some of the key processes that occur during the intestinal response to GI nematode infections. Three main compartments are illustrated (gut mucosa, mesenteric lymph nodes and bone marrow) and the arrows link boxes within these to illustrate the steps that follow after invasion of the intestinal lumen and mucosa (represented by the horizontal tube) by worms. These include initial recognition of foreign antigens, antigen processing, activation of B and Th2 lymphocytes, secretion of antibody and cytokines, recruitment of effector cells from the bone marrow and direct effects on the mucosa.

types respond to different combinations of molecular signals during the induction phase and depend on different signals for their eventual homing to the sites where they express their effector functions (Urban et al., 2000; Else \& deSchoolmeester, 2003). Thus, overall orchestration of the protective intestinal response is a complex process that we are still unravelling at the molecular level (McDermott et al., 2001; Else \& deSchoolmeester, 2003). The availability of knock-out mice, in which the genes for specific components of the response have been inactivated, has clarified the essential requirement of cell adhesion molecules, cytokines such as interleukin(IL)-4, IL-9, IL-10 and IL-13 and the STAT6 signalling system in the expulsion of Trichinella spiralis, Trichuris muris, Nippostrongylus brasiliensis and resistance to Heligmosomoides polygyrus (Urban et al., 1991, 1998, 2000; Bancroft et al., 1998; Greenwald et al., 1999; Schopf et al., 2002) and has identified interesting and informative differences in the precise requirements for host-protective immunity for different species (e.g. N. brasiliensis where IL-4 is not essential for worm loss, at least in mice; Lawrence et al., 1996).

Such studies, as well as those employing transgenic strains in which specific cytokine secretion is upregulated and the recent use of chimaeric mice in combination with knockout genetic status, have demonstrated that there is considerable redundancy in the overall response (Finkelman et al., 1991; Meeusen \& Balic, 2000). While in each case, the afferent arm of the response, in which antigen is recognized and Th2 cells are activated, is very similar and drives events, eventually a range of effector mechanisms is activated, only some of which may be essential for loss of the initiating species. One of the most dramatic consequences of infection with gastrointestinal (GI) nematodes is the enormous influx of mast cells that occurs in the intestinal mucosa, first noted during $N$. brasiliensis infections in rats (Wells, 1962; Miller,
1971; Nawa \& Miller 1979). However, the mast cell response in this host-parasite combination is now considered to be redundant and not essential for worm loss (Abe et al., 1992). Rather, it is the goblet cell response involving the secretion of mucus that is crucial for expulsion of $N$. brasiliensis from rats and mice (Ishikawa et al., 1993; Nawa et al., 1994). Similarly, mast cells play little role in protective immunity to T. muris (Betts \& Else, 1999), even though marked mastocytosis occurs in the caecum during primary infection (Lee \& Wakelin, 1982). In contrast, the mast cell response is essential for expulsion of both adult T. spiralis and Strongyloides ratti. This range of effectors presumably evolved over time as hosts had to contend with a variety of different intestinal nematodes with varying effects on host fitness, and employing different strategies for evading specific components of host protective resistance (Behnke et al., 2000).

\section{The essential nature of key genes}

The complexity of the overall response, and the requirement for it to be precisely orchestrated, implies that many genes must be involved, that hierarchical relations exist between them and that they become activated in a particular sequence (Artis et al., 1999; Schopf et al., 2002). The deletion of a key gene for an essential central process in the sequence may abrogate the response altogether. In fact the discovery of the nude mouse is one such example. Nude, or athymic mice, are unable to expel GI nematodes because they lack T cells (Jacobson \& Reed, 1974), and this is attributed to just a single gene defect in a transcription factor that controls the generation of the thymic anlage and concurrently the development of hair papillae (Nehls et al., 1994). Deletions of additional genes downstream can also block worm expulsion (Schopf et al., 2002), but nevertheless may 
enable some of the other component processes to proceed relatively normally and vice versa. For example IL-13 knockout mice, which do not expel T. muris, eventually generate strong Th2 responses including mastocytosis and exaggerated parasite-specific IgG1 antibody responses (Bancroft et al., 1998). In contrast, IL-5 knockout mice do not show eosinophilia but expulsion of GI nematodes is not slowed (Finkelman et al., 1991; Meeusen \& Balic, 2000).

\section{Natural variation in genes - alleles for resistance and susceptibility}

Natural mutations that severely affect immunocompetence exist in nature (e.g. immundeficiency diseases such as severe combined immunodeficiency or agammaglobulinaemia, DiGeorge syndrome, Janeway et al., 1997). However, in nature, animals do not survive such dramatic deficiencies in key components of the immune response, and genetically-determined variation is usually quantitative, allowing survival but resulting in differences between individuals. Under conditions of natural exposure to infection a range of other intrinsic (e.g. age, sex, reproductive status) and extrinsic (season, location climate, etc.) factors may also influence susceptibility and resistance to infection, so the genetic component is not always easy to identify. When the conditions of exposure are similar, differences in immunocompetence may be attributable to a large degree to differences in alleles of some of the key genes in the gene cascade that drives the response. One set of such alleles (haplotype) may enable a host to respond quickly, facilitating rapid clearance of worms, whilst a different haplotype can at best mediate a slow response or at worst no effective host protection.

It has been known for some time that breeds of domestic livestock differ in their capacities to control or resist GI nematode infections (Ackert et al., 1933; Stewart et al., 1937). Native breeds that have developed under conditions where parasite challenge is high, often have enhanced resistance to the locally most important GI nematode species, (e.g. Haemonchus contortus; Gray et al., 1995). Such breeds as the Red Massai in East Africa, Louisiana Native in the USA, St. Croix in the Caribbean and the Javanese Thin Tail sheep in Indonesia, have been naturally selected for resistance (Preston \& Allonby, 1979; Courtney et al., 1985; Baker et al., 1992, 1999, 2003; Baker, 1998 ) and therefore, carry alleles for resistance on some of the crucial genes involved.

This variation in capacity to respond to GI nematodes is also replicated in laboratory model systems that exploit combinations of syngeneic (inbred) mouse strains and murine nematodes (Wakelin, 1978, 1985, 1988, 2000; Bell, 1998).

\section{Heritability of resistance to GI nematodes}

The genetic basis of variation in resistance to nematode infections in mammals was initially suggested in the 1950s in work with $H$. contortus (Whitlock, 1955), but the first laboratory demonstration that indisputably confirmed the heritability of resistance to GI nematodes was based on work with T. muris in Schofield mice. Wakelin
(1975) showed that Schofield mice, approximately $70 \%$ of which normally clear T. muris infection, could be selectively bred to enhance resistance from $70 \%$ to $100 \%$. In contrast, whilst initially approximately $30 \%$ of the parental stock failed to clear infection and therefore sustained chronic infection, the percentage could be increased to $70-80 \%$ by selective breeding for susceptibility (fig. 2). The experiments were continued until the sixth generation, at which time the resistant line was solidly resistant to infection whereas the susceptible line still included about $20-30 \%$ of individuals that managed to resist infection. This experiment suggested that more than a single gene is involved in determining whether Schofield mice resist or expel worms, and that the alleles for resistance are dominant. In the 1980s many other studies, based both on laboratory model systems (Brindley \& Dobson, 1982; Bell, 1998) and on parasites of livestock, predominantly sheep parasites, expanded on this earlier work (Windon \& Dineen, 1984; Albers \& Gray, 1987; Gray, 1987) and established that in livestock heritability of resistance is generally of the order of about 0.2-0.4 (Kloosterman et al., 1992; Gasbarre \& Miller, 2000).

\section{MHC based genes}

Mouse strains differ profoundly in their responses to T. muris (fig. 3), T. spiralis (Wakelin, 1988; Bell, 1998) and H. polygyrus (Behnke \& Wakelin, 1977; Behnke \& Robinson, 1985; Enriquez et al., 1988a). However, it was soon realized that, in certain systems, strains that showed the same MHC haplotype behaved similarly although not identically to one another (Wassom et al., 1979). Thus, whilst mouse strains with the $\mathrm{H}-2^{\mathrm{q}}$ haplotype (DBA/1, SWR, BUB/Bn) showed varying levels of resistance, all these strains were better at resisting T. spiralis than strains with the $\mathrm{H}-2^{\mathrm{k}}$ haplotype (e.g. $\mathrm{C} 3 \mathrm{H}, \mathrm{CBA}, \mathrm{AKR}$ ). As in other parasitic, bacterial and viral infections, $\mathrm{H}-2$ based genes may therefore account for some of the variation between strains and, by extrapolation, for a significant proportion of naturally occurring variation in disease resistance (Wakelin \& Blackwell, 1988; Cooke \& Hill, 2000).

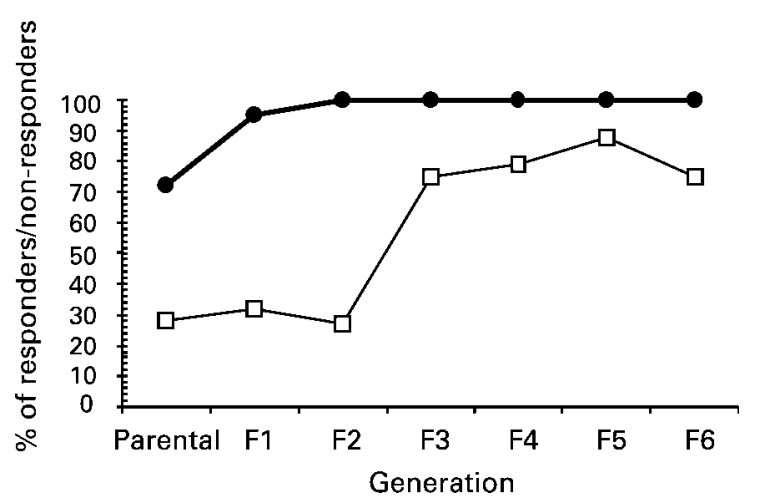

Fig. 2. Selection for resistance and susceptibility to infection with Trichuris muris in Schofield mice (Wakelin, 1975). Non-responder line $(\square)$ and responder line $(\bullet)$ mice. 


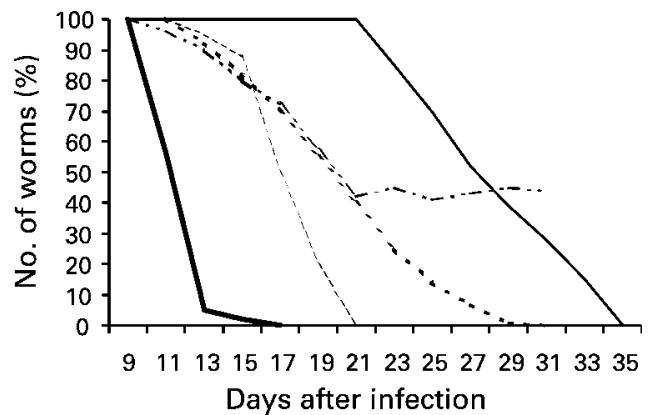

Fig. 3. Variation in the course of infection with Trichuris muris in five strains of inbred mice (-, $\mathrm{NIH}$; - - , CBA; - - - $\mathrm{C} 3 \mathrm{H} ;----$, DBA2; - , A) (Data from Wakelin 1978).

A complementary laboratory approach exploited $\mathrm{H}-2$ congenic strains, in which the background genes are identical and the $\mathrm{H}-2$ genes have been switched by selective breeding and backcrossing. The availability of a large range of strains on the B10 (C57BL10) background and a limited range on the BALB background enabled the role of MHC genes to be confirmed. Again, in respect of T. spiralis, the $\mathrm{H}-2^{\mathrm{k}}$ haplotype was shown to be associated with susceptibility (B10-BR), whereas H-2 ${ }^{\mathrm{q}}$ (B10.Q) and $\mathrm{H}-2^{\mathrm{s}}$ (B10.S) were both resistant haplotypes. Much the same picture emerged for $H$. polygyrus (Enriquez et al., 1988b) although for T. muris, $\mathrm{H}-2^{\mathrm{k}}$ carrying mouse strains varied, some showing capacity to expel the parasite (CBA and BALB/k) while others failed to do so (B10.BR; Else \& Wakelin, 1988).

Collectively these studies established an important role of variation among the MHC alleles in predisposing resistance/susceptibility to infection with GI nematodes in rodents. They were followed by studies demonstrating that MHC genes also play a role in regulating GI nematode infections in sheep (Outteridge et al., 1985, 1988; Schwaiger et al., 1995; Stear et al., 1996; Paterson et al., 1998) and other domestic animals (Stear et al., 1988; Stear \& Wakelin, 1998). The MHC locus encodes primarily genes that are involved in recognition of foreignness (non-self), including the class 1 and class 2 antigen presenting molecules on cells such as macrophages and dendritic cells. These findings were therefore in accord with the proposed mechanisms of resistance as illustrated in fig. 1. However, they emphasized that genes outside the MHC, background genes, also play a role, in fact if anything, a more important role in this respect (Bell, 1998). Figure 4 shows that loss of $H$. polygyrus from B10.S $\left(\mathrm{H}-2^{\mathrm{s}}\right)$ mice is more rapid than from B10 $\left(\mathrm{H}-2^{\mathrm{b}}\right)$ mice, which differ only in alleles at the MHC, but it is considerably faster in SJL mice, that share $\mathrm{H}-2$ with B10.S but differ in other parts of their genome (Behnke \& Wahid, 1991).

Whilst there was no possibility at this stage to investigate further the background genes, the availability of MHC recombinant mice in Chella David's laboratory enabled the MHC genes involved in resistance to $T$. spiralis to be localized more precisely (Wassom et al., 1979). This led to the hypothesis that at least two genes, mapping within the MHC were

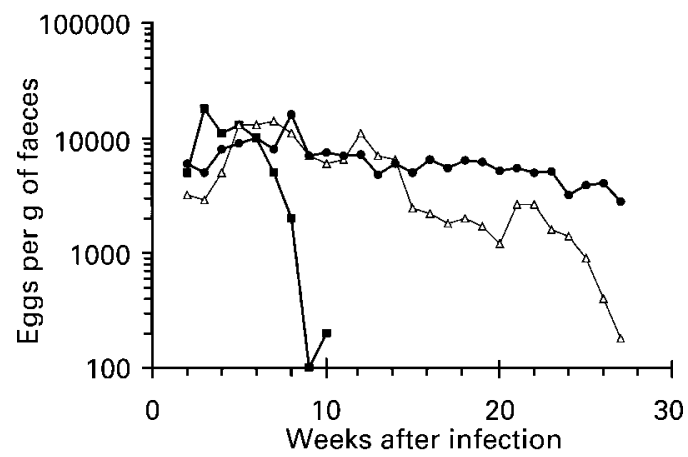

Fig. 4. Comparison of the rate of loss of Heligmosomoide polygyrus, as reflected through faecal egg counts, from three strains of mice. $\mathrm{B} 10(\bullet)$ and B10.S $(\triangle)$ mice differ in MHC haplotype but have the same alleles for other genes. B10.S and SJL (口) mice share MHC haplotype but the alleles of their non-MHC background genes differ. (Data from Behnke \& Wahid, 1991).

involved. The first of these, the Ts- 1 gene was shown to map to the I-A locus, and in this case the $s$ haplotype facilitated resistance and the $k$ haplotype susceptibility. The second was shown to map to a region between the $\mathrm{S}$ and $\mathrm{D}$ loci of the $\mathrm{H}-2$. Here the $b$ and $s$ haplotypes were linked to resistance, and the $d$ haplotype with susceptibility (Wassom et al., 1983). Comparable studies on $H$. polygyrus established that two MHC genes were also involved and that the Ts- 1 locus was probably also crucial for resistance to this species (Enriquez et al., 1988b).

Drawing on all of their individual and combined studies, in 1984 Wassom et al. put forward their hypothesis concluding that 'the anti-adult response, the anti-fecundity response and the rapid expulsion response are under independent genetic control and influenced by the interacting products of both $\mathrm{H}-2$ and non H-2 genes'. In other words, genetic differences between animals at several loci, both in the MHC and outside the MHC, influence resistance to infection and different combinations of genes may be responsible for different manifestations of resistance, such as effects on faecal egg counts, growth of worms, and worm burdens (fig. 5).

Other studies supported the idea that non-MHC genes played a significant role in worm expulsion (Bell, 1988) and that MHC genes moderated or fine-tuned the influence of non-MHC genes (Bell, 1998), but the loci of these non-MHC genes have proved to be elusive. Currently with just two exceptions, mapping of the genes whose different alleles influence susceptibility/ resistance to infection has been focused on the MHC (table 1). One exception is a gene on chromosome 4, linked to the FV-1 locus, that influences the accumulation of muscle larvae in T. spiralis (Wassom et al., 1987). The second exception is the interferon-gamma (IFN- $\gamma$ ) gene on chromosome 3 in the ovine genome, which has been identified as playing an important role in predisposing resistance to $H$. contortus in farmed sheep in Australia (Crawford \& McEwen, 1998; Paterson et al., 2001) and in a wild population of Soay sheep living on the island of Hirta in the outer Hebrides (Coltman et al., 2001). 


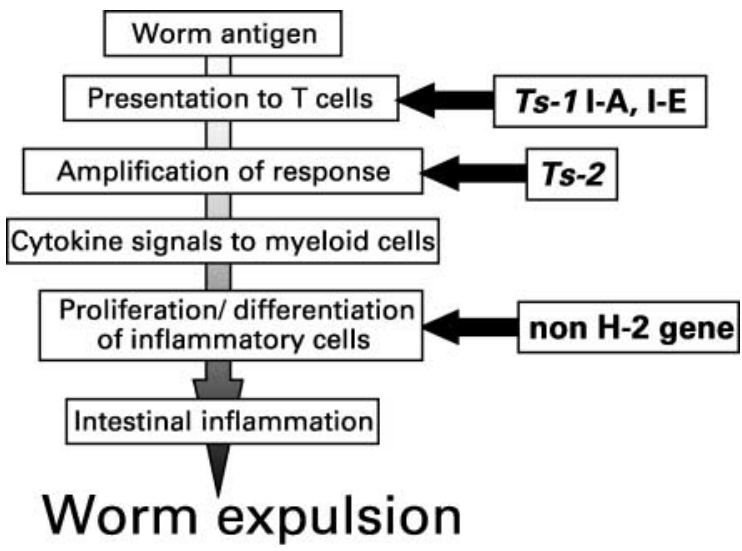

Fig. 5. Schematic representation of the stages at which Wassom et al. (1984) hypothesized that genes controlling the response to Trichinella spiralis exerted their influence on worm expulsion.

\section{A different approach - linkage mapping exploiting microsatellites}

The exploitation of syngeneic mouse strains, their $\mathrm{H}-2$ congenic and recombinant strains enabled significant progress, and was facilitated largely by the perceived importance of the MHC not only in resistance to parasites but also many other diseases. However, the MHC genes constitute only a small fraction of the murine genome, spanning less than $10 \%$ of chromosome 17 (approximately $8 \mathrm{Mb}$, and $5 \mathrm{cM}$ ) and occupying less than $0.3 \%$ of the genetic distance across all the chromosomes combined (Allcock et al., 2000). Loci for the other, non-MHC, genes were not known and could potentially reside anywhere among the remaining 19 murine chromosomes as well as on non-MHC encoding sections of chromosome 17. An alternative approach was required.

By the 1990s microsatellite technology had achieved major progress and by 1996 over 7000 microsatellite markers were available mapping right across the mouse genome (Dietrich et al., 1996). Since then many additional markers have been developed for the murine genome as well as those of humans and domestic animals, and these have been exploited successfully to map quantitative trait loci (QTL) for various traits including disease resistance (Crawford, 2001; Korstanje \& Paigen, 2002). The first QTL to be mapped successfully for resistance to parasites were those for trypanosome infections in mice (Kemp et al., 1997; Kemp \& Teale, 1998; Iraqi et al., 2000).

Considerable progress has been made since with mapping the QTL for resistance to GI nematode infections in sheep, where attention has been focused on a region of chromosome 3 that includes the IFN- $\gamma$ gene (Crawford \& McEwen, 1998; Paterson et al., 2001). Polymorphism in this region (o(IFN)- $\gamma_{126}$ ) was also linked to reduced faecal egg counts and increased parasite specific IgA in a wild population of Soay sheep on the island of Hirta in the St Kilda archipelago in the Outer Hebrides (Coltman et al., 2001)

In the human context, Williams-Blangero et al. (2002) have recently identified QTL for susceptibility to Ascaris lumbricoides in a community in eastern Nepal, mapping to chromosomes 1 and 13. The strongest effect was on chromosome 13, where the QTL spanned a 20-cM region located in the distal end of this chromosome, a region where relatively few genes have been identified. However, a gene from the tumour necrosis factor superfamily of cytokines (TNFSF13B) is located here and since TNSF13B is considered to be a regulator of B lymphocyte function it was proposed as the candidate gene responsible for the QTL. No candidates were identified for the gene on chromosome 1, but another interesting locus on chromosome 8 that did not achieve overall significance in genome-wide analysis coincided with the loci for IL-7 and for activated B-cell factor (ABF1), which are involved in mucosal immunity and B cell function respectively.

\section{Mapping the QTL for Heligmosomoides polygyrus}

In 1998 we initiated a project to begin mapping the QTL for resistance to $H$. polygyrus in mice. We chose

Table 1. Loci of genes known to be involved in resistance to gastrointestinal nematodes.

\begin{tabular}{|c|c|c|c|c|c|c|}
\hline \multirow[b]{2}{*}{ Species } & \multirow[b]{2}{*}{ Host } & \multirow[b]{2}{*}{ Designation } & \multirow[b]{2}{*}{ Locus } & \multicolumn{2}{|c|}{ Alleles } & \multirow[b]{2}{*}{ Reference } \\
\hline & & & & $\mathrm{R}^{*}$ & $S^{*}$ & \\
\hline T. spiralis & Mice & Ts1 & $\mathrm{H}-2, \mathrm{I}-\mathrm{A} \beta$ & $\mathrm{s}, \mathrm{g}, \mathrm{f}, \mathrm{b}$ & $\mathrm{k}$ & Wassom et al., 1983 \\
\hline T. spiralis & Mice & Ts2 & $\mathrm{H}-2$, between $\mathrm{S} \& \mathrm{D}$ & $\mathrm{s}, \mathrm{b}$ & $\mathrm{d}$ & Wassom et al., 1983 \\
\hline T. spiralis & Mice & $?$ & near FV-1 chrom 3 & & & Wassom et al., 1987 \\
\hline H. polygyrus & Mice & $?$ & H-2 left of I-E $\alpha$ & $\mathrm{q}, \mathrm{f}, \mathrm{s}$ & $\mathrm{k}$ & Enriquez et al., $1988 b$ \\
\hline H. polygyrus & Mice & $?$ & $\mathrm{H}-2, \mathrm{D}$ end & & & Enriquez et al., $1988 \mathrm{~b}$ \\
\hline T. muris & Mice & $?$ & $\mathrm{H}-2, \mathrm{I}-\mathrm{A}$ & $\mathrm{q}, \mathrm{b}$ & $\mathrm{k}, \mathrm{d}$ & Else et al., 1990 \\
\hline T. muris & Mice & ? & $\mathrm{H}-2, \mathrm{D}$ end & q & $\mathrm{b}, \mathrm{d}$ & Else et al., 1990 \\
\hline T. circumcincta & Sheep & $?$ & MHC-DRB1 & G2 & I & Schwaiger et al., 1995 \\
\hline T. circumcincta & Sheep & $?$ & MHC-DRB1 & $?$ & $?$ & Buitkamp et al., 1996 \\
\hline T. circumcincta & Sheep & $?$ & MHC-DY & $?$ & ? & Buitkamp et al., 1996 \\
\hline T. circumcincta & Sheep & $?$ & $o($ IFN $)-\gamma$ chrom. $3 q$ & 126 & 130 & Coltman et al., 2001 \\
\hline T. circumcincta & Sheep & $?$ & MHC OLADRB & 263 & 257,267 & Paterson et al., 1998 \\
\hline H. contortus & Sheep & $?$ & IFN- $\gamma$ chrom. $3 q$ & $\mathrm{~A}$ & $\mathrm{~B}$ & Paterson et al., 2001 \\
\hline
\end{tabular}

${ }^{*} \mathrm{R}$, alleles associated with resistance; $S$, alleles associated with susceptibility. 
H. polygyrus because this is a well studied species (Monroy \& Enriquez, 1992) with which we have worked for many years in Nottingham, and one with which we were very familiar (Behnke, 1987). Moreover, in contrast to T. spiralis and T. muris, it is arguably more relevant as a model for understanding resistance in domestic livestock because it is more closely related to species such as $H$. contortus, Teladorsagia circumcincta and Trichostrongylus colubriformis (Durette-Desset, 1985). Another key difference between $H$. polygyrus and the other murine species is that it does not normally elicit a rapid protective response in mice, but rather single pulse laboratory infections result in worms surviving for more than 30 weeks and even longer (Robinson et al., 1989). It is therefore a convenient and relevant model of chronic GI nematode infections, such as those experienced by domestic ruminants grazing on pasture (Behnke, 1987; Behnke et al., 1992; Monroy \& Enriquez, 1992). We also chose a trickle infection protocol to mimic the continuous acquisition of larvae that occurs as animals graze on pasture (Brailsford \& Behnke, 1992).

The selection of mouse strains to be used as founders of the resource population for mapping was also critical. We chose CBA $\left(\mathrm{H}-2^{\mathrm{k}}\right)$ mice because this strain is well documented as harbouring long chronic primary infections, responding slowly with antibody and mucosal mastocytosis, and not readily acquiring immunity to re-infection (Behnke \& Robinson, 1985; Robinson et al., 1989; Wahid et al., 1994). Our second strain was the SWR $\left(\mathrm{H}-2^{\mathrm{q}}\right)$, which expels primary infections within 6-8 weeks of exposure to third-stage larvae (L3s), responds rapidly with mast cells and antibodies, and becomes solidly resistant to re-infection after minimal experience of L3s (Wahid et al., 1989). Moreover, these two strains showed the contrasting MHC haplotypes that had earlier been linked with susceptibility and resistance.

The time course of infection in a pilot experiment is summarized in fig. 6a. This shows that worm burdens accumulated in CBA mice to achieve a plateau in week 4 , by which time the worm burden was about $400-500$ worms per mouse. In contrast, SWR mice resisted infection from the outset and by week 4, despite continued weekly re-infection, were solidly resistant to further infection. We monitored several accompanying immune responses throughout these pilot experiments and eventually chose four for inclusion in our search for QTL for resistance. As can be seen from fig. 6b, the mucosal mast cell 1 (MMCP1) response differed markedly between the two strains, peaking in weeks 2 and 3 in SWR mice just preceding the loss of established adult worms, whilst increasing comparatively slowly in CBA mice.

Week 6 was eventually chosen as the optimal time to conduct worm counts. We monitored egg counts in weeks 2, 4 and 6. Mucosal mast cell 1 levels were recorded in week 3 , and the granulomatous response, $\operatorname{IgE}$ to fourth stage larvae and IgG1 to adult worm antigens in week 6, when the responses in the parental strains were most divergent. In total, we phenotyped 514 F2 mice in 13 separate experiments (40 F2/experiment), each of which was controlled by the inclusion of parental strain mice of both sexes. For genotyping we selected 272 mice
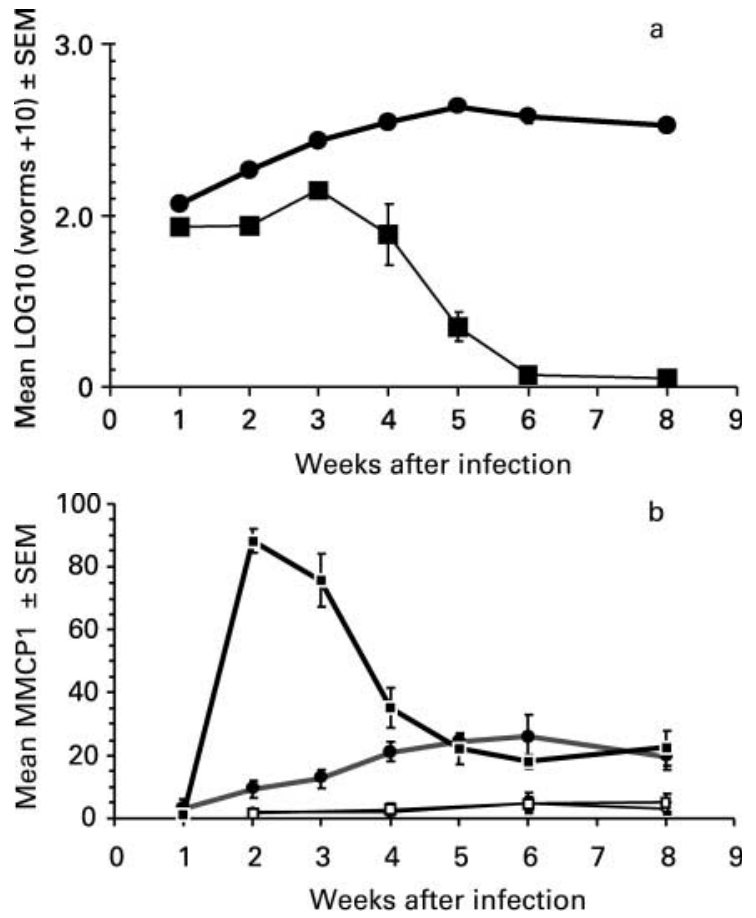

Fig. 6. (a) Changes in worm burden during the course of trickle infection with Heligmosomoides polygyrus in SWR $(\boldsymbol{\square})$ and CBA $(\bullet)$ mice. (b) The concentration of MMCP1 in the serum of SWR (ם) and CBA $(\bullet)$ mice during the course of trickle infection with $H$. polygyrus and in naïve uninfected SWR $(\square)$ and CBA (O) control mice.

representing 155 of the most resistant and 117 of the most susceptible animals. These were screened on chromosomes 1, 11, 12 and 17. Of the 272, 204 were screened on all the remaining autosomes and the $X$ chromosome. To achieve nearly $100 \%$ genome coverage 175 informative microsatellites were used.

Figure 7 summarizes the details for the four QTL that were unequivocally significant, and as can be seen these are located on chromosomes 1, 2, 13 and 17 (Menge et al., 2002; Iraqi et al., 2003). Each QTL spans regions of 20-30 $\mathrm{cM}$ but in all four cases the alleles for resistance came from SWR mice, and in all cases the alleles for resistance were dominant, as we had predicted from our earlier observations. There is no certainty as to which genes are involved at this stage but some candidate genes can be suggested. Consistent with earlier studies in congenic mice, a significant QTL for worm counts lies on chromosome 17 in the region of MHC. However, the $\mathrm{MHC}$ region also encompasses other, non-MHC (e.g. TNF locus), genes and it is possible that fine mapping may eventually identify some of these as playing a significant role in resistance. The QTL on chromosome 13 encompasses the gene for IL-9 and this is also of interest since upregulation of this cytokine in IL-9 transgenic strains, which constitutively express high levels of IL-9, leads to rapid clearance of adult worm burdens (R.K. Grencis et al., personal communication). We have also recognized a significant QTL on chromosome 17 for the early fecundity response (faecal egg counts in week 2), that maps to the distal region of this chromosome and for which the allele 


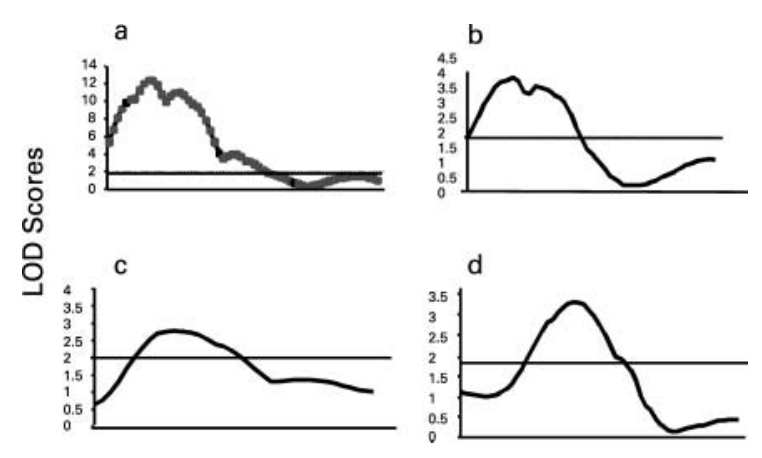

Fig. 7. Quantitative trait loci for worm burdens on four murine chromosomes. The figure shows the LOD score for worm burdens at week 6, across each of the chromosomes (proximal end is on the left and the distal on the right of each graph) where a significant QTL was found to segregate. Some candidate genes known to have loci within the range of each QTL are given in brackets. (a) chromosome 1 (IL-1r (type 1 and 2), Stat 4, and CD 28); (b) chromosome 19 (MHC, MCP 6 and 7 and trefoil factors 1-3); (c) chromosome 13, (T cell receptor $\gamma$ chain and IL-9); (d) chromosome 2 (Integrin $\alpha 2$ and RAG1 and RAG2). A value greater than 2 is indicative of a QTL segregating at the locus but note that all data were fully analysed by appropriate statistical methods. (Data from Iraqi et al., 2003.)

for resistance comes from CBA mice (Iraqi et al., 2003). Several QTL for the accompanying immunological responses have been identified (Menge et al., 2002) but it is still too early to present a clear picture of these. However, it is apparent that neither worm counts, nor faecal egg counts are prominently linked to any QTL for the immunological measures that we quantified other than those on chromosome 17. Here the QTL for all four measures superimpose on those for worm counts in the proximal region of this chromosome. If these QTL are eventually fine mapped to the MHC, one interpretation may be that once recognition has occurred, all the effectors are activated, even if they do not reflect a crucial component of the mechanism responsible for protective immunity. This concept of redundancy in the effector mechanisms elicited by type 2 responses to any specific nematode has been discussed earlier. It is consistent with the idea that the current complexity of intestinal responses evolved through selection pressure on hosts from a large range of mucosal pathogens with their own antigenic characteristics and intricate evasion strategies (Finkelman et al., 1991; Behnke et al., 2000).

\section{The future}

In order to fine map the QTL identified in the F2 resource population, we have already completed the phenotyping for worm counts and faecal egg counts of 1095 F6/F7 hybrids (advanced intercross line (AIL) population). The accompanying immune responses are still undergoing analysis and the genotyping is well under way. After completion of the fine mapping, we will apply multiple approaches for high resolution mapping (Iraqi, 2000) of the QTL to even more precise genomic regions and eventually confirm the genes underlying the
QTL by cloning. In turn, this information will facilitate and simplify the search for homologues in the genomes of humans and sheep (Zadissa et al., 2001). The latter will be aided by the parallel programme at the International Livestock Research Institute mapping QTL for resistance to GI nematodes in sheep (Okomo et al., 2000) and, once these are known, they will provide a valuable tool for selective breeding of sheep to improve resistance. Genetic markers will greatly accelerate the development of genetic resistance in productive breeds that are currently threatened throughout the pastoral regions of the globe by the rapid spread and growing threat of resistance to anthelmintic drugs among GI nematodes of domestic small ruminants (Waller, 1986, 1997; Coles, 1998; Jackson \& Coop, 2000).

If economically feasible, genetic markers for susceptibility in humans could facilitate targeted anthelmintic use and thereby help to offset and hopefully avoid altogether the threat of anthelmintic resistance. Species such as hookworms still pose a continuing threat to communities in the tropics and poor responses to anthelmintic treatment, suggestive of drug resistance, have been reported recently (De Clercq et al., 1997; Reynoldson et al., 1997). Alongside development programmes aiming to improve water quality and sanitation facilities, another approach may be through education attempting to change sanitary behaviour and emphasizing the need for footwear in the case of hookworms, focusing in particular on the susceptible sectors of human communities, once these have been identified. Finally, awareness of the genetically determined resistance status of subjects may have implications for efficient vaccine delivery in the future, since it is precisely the susceptible individuals who will benefit most from vaccines.

\section{Acknowledgements}

The authors gratefully acknowledge grants 053419/Z/98/Z and 063810/Z/01/A from the Wellcome Trust. We thank Simon Clifford, Anna Lowe, Jill Brown and David Fox for contributions to this work in Nottingham and Bob King, John Mugambi, John Wambugu, Moses Ogugo, Daniel Mwangi and Nemwel Nyemweya at ILRI in Kenya.

\section{References}

Abe, T., Sugaya, H., Yoshimura, K. \& Nawa, Y. (1992) Induction of the expulsion of Strongyloides ratti and retention of Nippostrongylus brasiliensis in athymic nude mice by repetitive administration of recombinant interleukin-3. Immunology 76, 10-14.

Ackert, J.E., Eisenbrandt, L.L., Glading, B. \& Wilmoth, J.H. (1933) On the comparative resistance of six breeds of chickens to the nematode Ascaridia lineata (Schneider). Journal of Parasitology 20, 127.

Albers, G.A.A. \& Gray, G.D. (1987) Breeding for worm resistance: a perspective. International Journal for Parasitology 17, 559-566.

Allcock, R.J.N., Martin, A.M. \& Price, P. (2000) The mouse as a model for the effects of MHC genes on human disease. Immunology Today 21, 328-334. 
Artis, D. \& Grencis, R.K. (2001) T helper cytokine responses during intestinal nematode infection: induction, regulation and effector function. pp. 311-371 in Kennedy, M.W. \& Harnett, W. (Eds) Parasitic nematodes: molecular biology, biochemistry and immunology. Wallingford, Oxon, CAB International.

Artis, D., Humphreys, N.E., Bancroft, A.J. Rothwell, N.J., Potten, C.S. \& Grencis, R.K. (1999) Tumor necrosis factor a is a critical component of interleukin 13-mediated protective T helper cell Type 2 responses during helminth infection. Journal of Experimental Medicine 190, 953-962.

Baker, R.L. (1998) A review of genetic resistance to gastrointestinal nematode parasites in sheep and goats in the tropics and evidence for resistance in some sheep and goat breeds in sub-humid coastal Kenya. Animal Genetics Resources Information Bulletin 24, 13-30.

Baker, R.L., Lahlou Kassi, A., Rege, J.E.O., Reynolds, L., Bekele, T., Mukassa-Mugerwa, E. \& Rey, B. (1992) A review of genetic resistance to endoparasites in small ruminants and an outline of ILCA's research programme in this area. Proceedings of the tenth scientific workshop of the small ruminant collaborative research support program, Nairobi 10, 97-104.

Baker, R.L., Mwamachi, D.M., Audho, J.O., Aduda, E.O. \& Thorpe, W. (1999) Genetic resistance to gastrointestinal nematode parasites in Red Maasai, Dorper and Maasai $\times$ Dorper ewes in the sub-humid tropics. Animal Science 69, 335-344.

Baker, R.L., Nagda, S., Rodriguez-Zas, S.L., Southey, B.R., Audho, J.O., Aduda, E.O. \& Thorpe, W. (2003) Resistance and resilience to gastro-intestinal nematode parasites and productivity of Red Maasai, Dorper and Red Maasai $\times$ Dorper crossbred lambs in the subhumid tropics. Animal Science 76, 111-136.

Bancroft, A.J., McKenzie, A.N.J. \& Grencis, R.K. (1998) A critical role for IL-13 in resistance to intestinal nematode infection. Journal of Immunology 160, 3453-3461.

Behnke, J.M. (1987) Evasion of immunity by nematode parasites causing chronic infections. Advances in Parasitology 26, 1-70.

Behnke, J.M., Lowe, A., Menge, D., Iraqi, F. \& Wakelin, D. (2000) Mapping the genes for resistance to gastrointestinal nematodes. Acta Parasitologica $45,1-13$.

Behnke, J.M. \& Robinson, M. (1985) Genetic control of immunity to Nematospiroides dubius: a 9-day anthelmintic abbreviated immunizing regime which separates weak and strong responder strains of mice. Parasite Immunology 7, 235-253.

Behnke, J.M. \& Wahid, F.N. (1991) Immunological relationships during primary infection with Heligmosomoides polygyrus (Nematospiroides dubius): $\mathrm{H}-2$ genes determine worm survival. Parasitology 103, 157-164.

Behnke, J.M. \& Wakelin, D. (1977) Nematospiroides dubius: stimulation of acquired immunity in inbred strains of mice. Journal of Helminthology 51, 167-176.

Behnke, J.M., Barnard, C.J. \& Wakelin, D. (1992) Understanding chronic nematode infections: evolutionary considerations, current hypotheses and the way forward. International Journal for Parasitology 22, 861-907.

Bell, R.G. (1988) Genetic analysis of expulsion of adult Trichinella spiralis in NFS, $\mathrm{C} 3 \mathrm{H} / \mathrm{He}$ and B10.BR mice. Experimental Parasitology 74, 417-465.

Bell, R.G. (1998) The generation and expression of immunity to Trichinella spiralis in laboratory rodents. Advances in Parasitology 41, 149-217.

Betts, C.J. \& Else, K.J. (1999) Mast cells, eosinophila and antibody-mediated cellular cytotoxicity are not critical in resistance to Trichuris muris. Parasite Immunology 21, $45-52$.

Brailsford, T.J. \& Behnke, J.M. (1992) The dynamics of trickle infections with Heligmosomoides polygyrus in syngeneic strains of mice. International Journal for Parasitology 22, 351-359.

Brindley, P.J. \& Dobson, C. (1982) Nematospiroides dubius in mice selected for liability to infection: modification of parasite biology through host selection. International Journal for Parasitology 12,573-578.

Buitkamp, J., Filmether, P., Stear, M.J. \& Epplen, J.T. (1996) Class I and class II major histocompatibility complex alleles are associated with faecal egg counts following natural, predominantly Ostertagia circumcincta infection. Parasitology Research 82, 693-696.

Coles, G.C. (1998) Drug-resistant parasites of sheep: an emerging problem in Britain? Parasitology Today 14, 86-88.

Coltman, D.W., Wilson, K., Pilkington, J.G., Stear, M.J. \& Pemberton, J.M. (2001) A microsatellite polymorphism in a gamma interferon gene is associated with resistance to gastrointestinal nematodes in a naturallyparasitized population of Soay sheep. Parasitology 122, $571-582$

Cooke, G.S. \& Hill, A.V.S. (2000) Genetics of susceptibility to human infectious disease. Nature Reviews in Genetics 2, 967-977.

Courtney, C.H., Parker, C.F., McClure, K.E. \& Herd, R.P. (1985) Resistance of exotic and domestic lambs to experimental infection with Haemonchus contortus. International Journal for Parasitology 15, 101-109.

Crawford, A.M. (2001) A review of QTL experiments in sheep. Proceedings of the Association for the Advancement of Animal Breedings and Genetics 14, 33-38.

Crawford, A.M. \& McEwen, J.C. (1998) Identification of animals resistant to nematode parasite infection. New Zealand Provisional Patent (330201), New Zealand .

De Clercq, D., Sacko, M., Behnke, J., Gilbert, F., Dorny, P. \& Vercruysse, J. (1997) Failure of mebendazole in treatment of human hookworm infections in the Southern Region of Mali. American Journal of Tropical Medicine and Hygiene 57, 25-30.

Dietrich, W.F., Miller, J., Steen, R., Merchant, M.A., Damron-Boles, D., Husain, Z., Dredge, R., Daly, M.J., Ingalls, K.A., O'Connor, T.J., Evans, C.A., De Angelis, M.M., Levinson, D.M., Kruglyak, L., Goodman, N., Copeland, N.G., Jenkins, N.A., Hawkins, T.L., Stein, L., Page, D.C. \& Lander, E.S. (1996) A comprehensive genetic map of the mouse genome. Nature 380, 149-152.

Durette-Desset, M.C. (1985) Trichostrongylid nematodes and their vertebrate hosts: reconstruction of the 
phylogeny of a parasitic group. Advances in Parasitology 24, 239-306.

Else, K.J. \& deSchoolmeester, M.L. (2003) Immunity to Trichuris muris in the laboratory mouse. Journal of Helminthology 77.

Else, K.J. \& Finkelman, F.D. (1999) Intestinal nematode parasites, cytokines and effector mechanisms. International Journal for Parasitology 28, 1145-1158.

Else, K.J. \& Wakelin, D. (1988) The effects of H-2 and non-H-2 genes on the expulsion of the nematode Trichuris muris from inbred and congenic mice. Parasitology 96, 543-550.

Else, K.J., Wakelin, D., Wassom, D.L. \& Hauda, K.M. (1990) The influence of genes mapping within the major histocompatibility complex on resistance to Trichuris muris infections in mice. Parasitology 101, 61-67.

Enriquez, F.J., Zidian, J.L. \& Cypess, R.H. (1988a) Nematospiroides dubius: genetic control of immunity to infections of mice. Experimental Parasitology 67, 12-19.

Enriquez, F.J., Brooks, B.O., Cypess, R.H., David, C.S. \& Wassom, D.L. (1988b) Nematospiroides dubius: two $\mathrm{H}$-2-linked genes influence levels of resistance to infection in mice. Experimental Parasitology 67, 221-226.

Finkelman, F.D., Pearce, E.J., Urban, J.F. \& Sher, A. (1991) Regulation and biological function of helminthinduced cytokine responses. Immunology Today 12, A62-A66.

Gasbarre, L.C. \& Miller, J.E. (2000) Genetics of helminth resistance. pp. 129-152 in Axford, R.F.E., Bishop, S.C., Nicholas, F.W. \& Owen, U.B. (Eds) Breeding for disease resistance in farm animals. 2nd edn, Wallingford, Oxon, CAB International.

Gray, G.D. (1987) Genetic resistance to haemonchosis in sheep. Parasitology Today 8, 253-255.

Gray, G.D., Woolaston, R.R. \& Eaton, B.T. (1995) Breeding for resistance to infectious diseases of small ruminants. Australian Centre for International Agricultural Research (ACIAR), Monograph No. 34. Canberra, Australia.

Greenwald, R.J., Urban, J.F., Ekkens, M.J., Chen, S.J., Nguyen, D., Fang, H., Finkelman, F.D., Sharpe, A.H. \& Gause, W.C. (1999) B7-2 is required for the progression but not the initiation of the Type 2 response to a gastrointestinal nematode parasite. Journal of Immunology 162, 4133-4139.

Iraqi, F. (2000) Fine mapping of quantitative trait loci using advanced intercross lines of mice and positional cloning of the corresponding genes. Journal of Experimental Lung Research 26, 641-649.

Iraqi, F.A., Behnke, J.M., Menge, D.M., Lowe, A., Teale, A.J., Gibson, J.P., Baker, L.R. \& Wakelin, D. (2003) Chromosomal regions controlling resistance to gastrointestinal nematode infections in mice. Mammalian Genome in press.

Iraqi, F., Clapcott, S.J., Kumari, P., Haley, C.J., Kemp, S.J. \& Teale, A.J. (2000) Fine mapping of trypanosomiasis resistance loci in murine advanced intercross lines. Mammalian Genome 11, 645-648.

Ishikawa, N., Horii, Y. \& Nawa, Y. (1993) Immunemediated alteration of the terminal sugars of goblet cell mucins in the small intestine of Nippostrongylus brasiliensis-infected rats. Immunology 78, 303-307.
Jackson, F. \& Coop, R.L. (2000) The development of anthelmintic resistance in sheep nematodes. Parasitology 120, S95-S107.

Jacobson, R.H. \& Reed, N.D. (1974) The immune response of congenitally athymic (nude) mice to the intestinal nematode Nippostrongylus brasiliensis. Proceedings of the Society for Experimental Biology and Medicine 147, 667-670.

Janeway, C.A. Jr., Travers, P., Hunt, S. \& Walport, M. (1997) Immunobiology. The immune system in health and disease. Edinburgh, Churchill Livingstone.

Kemp, S.J. \& Teale, A.J. (1998) Genetic basis of trypanotolerance in cattle and mice. Parasitology Today 14, 450-454.

Kemp, S., Iraqi, F., Darvasi, A., Soller, M. \& Teale, A.J. (1997) Localization of genes controlling resistance to trypanosomiasis in mice. Nature Genetics 16, 194-196.

Kloosterman, A., Parmentier, H.K. \& Ploeger, H.W. (1992) Breeding cattle and sheep for resistance to gastrointestinal nematodes. Parasitology Today 8, 330-335.

Korstanje, R. \& Paigen, B. (2002) From QTL to gene: the harvest begins. Nature Genetics 31, 235-236.

Lawrence, R.A., Gray, C.A., Osborne, J. \& Maizels, R.M. (1996) Nippostrongylus brasiliensis: cytokine responses and nematode expulsion in normal and IL-4 deficient mice. Experimental Parasitology 84, 65-73.

Lee, T.D.G. \& Wakelin, D. (1982) The use of host strain variation to assess the significance of mucosal mast cells in the spontaneous cure response of mice to the nematode Trichuris muris. International Archives of Allergy and Applied Immunology 67, 302-305.

McDermott, J.R., Grencis, R.K. \& Else, K.J. (2001) Leucocyte recruitment during enteric nematode infection. Immunology 103, 505-510.

Meeusen, E.N.T. \& Balic, A. (2000) Do eosinophils have a role in the killing of helminth parasites? Parasitology Today 16, 95-101.

Menge, D.M., Behnke, J.M., Iraqi, F., Lowe, A., Teale, A.J., Gibson, J.P., Wakelin, D. \& Baker, R.L. (2002) Quantitative trait loci for resistance to gastrointestinal nematode infections in mice. Proceedings of the 7th World Congress on Genetics Applied to Livestock Production 31, 707-710.

Miller, H.R.P. (1971) Immune reactions in mucous membranes II. The differentiation of intestinal mast cells during helminth expulsion in the rat. Laboratory Investigation 24, 339-347.

Monroy, F.G. \& Enriquez, F.J. (1992) Heligmosomoides polygyrus: a model for chronic gastrointestinal helminthiasis. Parasitology Today 8, 49-54.

Nawa, Y. \& Miller, H.R.P. (1979) Adoptive transfer of the intestinal mast cell responses in rats infected with Nippostrongylus brasiliensis. Cellular Immunology 42, 225-239.

Nawa, Y., Ishikawa, N., Tsuchiya, K., Hori, Y., Abe, T., Khan, A.I., Bing-Shi, Itohi, T., Ide, H. \& Uchiyama, F. (1994) Selective effector mechanisms for the expulsion of intestinal helminths. Parasite Immunology 16, 333-338.

Nehls, M., Pfeifer, D., Schorpp, M., Hedrich, H. \& Boehm, T. (1994) New member of the winged-helix protein family disrupted in mouse and rat nude mutations. Nature 372, 103-107. 
Okomo, M.A., Mugambi, J.M., Aduda, E.O., Hanotte, O. van Arendonk, J.A.M. \& Baker, R.L. (2000) Mapping quantitative trait loci controlling resistance to gastrointestinal nematode parasites in Red Maasai sheep. p. 25 in Proceedings of the 27th International Conference on Animal Genetics, 22-26 July, University of Minnesota, USA. Conference Abstract Book.

Outteridge, P.M., Windon, R.G. \& Dineen, J.K. (1985) An association between a lymphocyte antigen in sheep and the response to vaccination against the parasite Trichostrongylus colubriformis. International Journal for Parasitology 15, 121-127.

Outteridge, P.M., Windon, R.G. \& Dineen, J.K. (1988) An ovine lymphocyte antigen marker for acquired resistance to Trichostrongylus colubriformis. International Journal for Parasitology 18, 853-858.

Paterson, K.A., McEwan, J.C., Dodds, K.G. \& Crawford, A.M. (2001) Fine mapping a locus affecting host resistance to internal parasites of sheep. Proceedings of the Association for the Advancement of Animal Breeding and Genetics 14, 91-94.

Paterson, S., Wilson, K. \& Pemberton, J.M. (1998) Major histocompatibility complex variation associated with juvenile survival and parasite resistance in a large unmanaged ungulate population (Ovis aries L.). Proceedings of the National Academy of Sciences, USA 95, 3714-3719.

Preston, J.M. \& Allonby, E.W. (1979) The influence of breed on the susceptibility of sheep to Haemonchus contortus infection in Kenya. Research in Veterinary Science 26, 134-139.

Reynoldson, J.A., Behnke, J.M., Pallant, L.J. MacNish, M.G., Gilbert, F. \& Thompson, R.A.C. (1997) Failure of pyrantel in treatment of human hookworm infections (Ancylostoma duodenale) in the Kimberley region of north west Australia. Acta Tropica 68, 301-312.

Robinson, M., Wahid, F.N., Behnke, J.M. \& Gilbert, F.S. (1989) Immunological relationships during primary infection with Heligmosomoides polygyrus (Nematospiroides dubius): dose-dependent expulsion of adult worms. Parasitology 98, 115-124.

Schopf, L.R., Hoffman, K.F., Cheever, A.W., Urban, J.F. Jr. \& Wynn, T.A. (2002) IL-10 is critical for host resistance and survival during gastrointestinal helminth infection. Journal of Immunology 168, 2383-2392.

Schwaiger, F.W., Gostomski, D., Stear, M., Duncan, J.L., McKellar, Q.A., Epplen, J.T. \& Buitkamp, J. (1995) An ovine major histocompatibility complex DRB1 allele is associated with low faecal egg count following natural, predominantly Ostertagia circumcincta infection. International Journal for Parasitology 25, 815-822.

Stear, M.J. \& Wakelin, D. (1998) Genetic resistance to parasitic infection. Revue Scientifique et Technique Office International des Epizooties 17, 143-153.

Stear, M.J., Tierney, T.J., Baldock, F.C., Brown, S.C., Nicholas, F.W. \& Rudder, T.H. (1988) Class I antigens of the bovine major histocompatibility system are weakly associated with variation in faecal worm egg counts in naturally infected cattle. Animal Genetics 19, 115-122.

Stear, M.J., Bairden, K., Bishop, S.C., Buitkamp, J., Epplen, J.T., Gostomski, D., McKellar, Q.A.,
Schwaiger, F.W. \& Wallace, D.S. (1996) An ovine lymphocyte antigen is associated with reduced faecal egg counts in four-month-old lambs following natural predominantly Ostertagia circumcincta infection. International Journal for Parasitology 26, $423-428$

Stewart, M.A., Miller, R.F. \& Douglas, J.R. (1937) Resistance of sheep of different breeds to infestations by Ostertagia circumcincta. Journal of Agricultural Research 55, 923-930.

Urban, J.F. Jr., Katona, I.M., Paul, W.E. \& Finkelman, F.D. (1991) Interleukin 4 is important in protective immunity to a gastrointestinal nematode infection in mice. Proceedings of the National Academy of Sciences USA 88, 5513-5517.

Urban, J.F. Jr., Noben-Trauth, N., Donaldson, D.D., Maddens, K.B., Morris, S.C., Collins, M. \& Finkelman, F.D. (1998) IL-13, IL-4Ra, and Stat6 are required for the expulsion of the gastrointestinal nematode parasite Nippostrongylus brasiliensis. Immunity 8, 255-264.

Urban, J.F. Jr., Schopf, L., Morris, S.C., Orekhova, T., Madden, K.B., Betts, C.J., Gamble, H.R., Byrd, C., Donaldson, D., Else, K. \& Finkelman, F.D. (2000) Stat6 signaling promotes protective immunity against Trichinella spiralis through a mast cell- and $\mathrm{T}$ cell-dependent mechanism. Journal of Immunology 164, 2046-2052.

Wahid, F.N., Robinson, M. \& Behnke, J.M. (1989) Immunological relationships during primary infection with Heligmosomoides polygyrus (Nematospiroides dubius): expulsion of adult worms from fast responder syngeneic and hybrid strains of mice. Parasitology 98, 459-469.

Wahid, F.N., Behnke, J.M., Grencis, R.K., Else, K.J. \& Ben-Smith, A.W. (1994) Immunological relationships during primary infection with Heligmosomoides polygyrus: Th2 cytokines and primary response phenotype. Parasitology 108, 461-471.

Wakelin, D. (1975) Genetic control of immune responses to parasites: selection for responsiveness and nonresponsiveness to Trichuris muris in random-bred mice. Parasitology 71, 377-384.

Wakelin, D. (1978) Genetic control of suceptibility and resistance to parasitic infection. Advances in Parasitology 16, 217-308.

Wakelin, D. (1985) Genetic control of immunity to helminth infections. Parasitology Today 1, 17-23.

Wakelin, D. (1988) Helminth infections. pp. 153-224 in Wakelin, D. \& Blackwell, J.M. (Eds) Genetics of resistance to bacterial and parasitic infection. London, Taylor \& Francis.

Wakelin, D. (2000) Rodent models of genetic resistance to parasitic infections. pp. 107-126 in Axford, R.F.E., Bishop, S.C., Nicholas, F.W. \& Owen, U.B. (Eds) Breeding for Disease Resistance in Farm Animals. 2nd edn. Wallingford, Oxon, CAB International.

Wakelin, D. \& Blackwell, J.M. (Eds) (1988) Genetics of resistance to bacterial and parasitic infection. London, Taylor \& Francis.

Waller, P.J. (1986) Anthelmintic resistance in nematode parasites of sheep. Agricultural Zoology Reviews 1, 333-373. 
Waller, P.J. (1997) Anthelmintic resistance. Veterinary Parasitology 72, 391-412.

Wassom, D.L., David, C.S. \& Gleich, G.J. (1979) Genes within the major histocompatibility complex influence susceptibility to Trichinella spiralis in the mouse. Immunogenetics 9, 491-496.

Wassom, D.L., Brooks, B.O., Babisch, J.G. \& David, C.S. (1983) A gene mapping between the $S$ and $D$ regions of the H-2 complex influences resistance to Trichinella spiralis infections in mice. Journal of Immunogenetics 10, 371-378.

Wassom, D.L., Wakelin, D., Brooks, B.O., Krco, C.J. \& David, C.S. (1984) Genetic control of immunity to Trichinella spiralis infection of mice. Hypothesis to explain the role of $\mathrm{H}-2$ genes in primary and challenge infections. Immunology 51, 625-631.

Wassom, D.L., Krco, C.J. \& David, C.S. (1987) I-E expression and susceptibility to parasite infection. Immunology Today 8, 39-43.

Wells, P.D. (1962) Mast cell, eosinophil and histamine levels in Nippostrongylus brasiliensis infected rats. Experimental Parasitology 12, 82-101.

Whitlock, J.H. (1955) A study of inheritance of resistance to trichostrongylidosis in sheep. Cornell Veterinarian $45,422-439$.

Williams-Blangero, S., VandeBerg, J.L., Subedi, J., Aivaliotis, M.J., Rai, D.R., Upadhayay, R.P., Jha, B. \& Blangero, J. (2002) Genes on chromosomes 1 and 13 have significant effects on Ascaris infection. Proceedings of the National Academy of Sciences, USA 99, 5533-5538.

Windon, R.G. \& Dineen, J.K. (1984) Parasitological and immunological competence of lambs selected for high and low responsiveness to vaccination with irradiated Trichostrongylus colubriformis larvae. pp. 13-28 in Dineen, J.K. \& Outteridge, P.M. (Eds) Immunogenetic approaches to the control of endoparasites. Melbourne, CSIRO, Division of Animal Health.

Zadissa, A., Dodds, K.G. \& McEwan, J.C. (2001) Computational comparative mapping between mammalian species. Proceedings of the Association for the Advancement of Animal Breeding and Genetics 14, 99-102.

(Accepted 17 February 2003) (c) CAB International, 2003 